\title{
Metallurgy and Structure of Casting Alloy Cu-30Zn Cast in Sand Moulds
}

Jiri Machuta, Iva Nova, Josef Horacek

Fakulta strojní, Technical university of Liberec, 46117 Liberec, Czech Republic., E-mail: jiri.machuta@tul.cz, iva.nova@tul.cz, josef.horacek1@tul.cz.

Currently at our department - Department of Engineering Technology - Technical University in Liberec), we are under-tracking properties of copper alloys. This article is dedicated of the brass $(\mathrm{Cu}-30 \mathrm{Zn})$, which is used for production of decorative castings. With production of decorative castings deal various foundries in the Czech Republic. The staff of these foundries for long periods gained a lot of experience in metallurgy and preparation of the copper alloy melts. In terms of our foundry there is little available literature data, which would characterize the crystallization and solidification of castings produced from single and multicomponent brass. Our department is involved in research of copper and its alloys. This article contains a description of crystallization of copper alloys $(70 \%)-\mathrm{Cu}-30 \mathrm{Zn}$ and proving phase analysis structure of the production of test casting shape of desk in the sand mould.

Keywords: brass, decorative castings, metallurgy alloys, crystallization, microstructure

\section{Acknoledgement}

The article is published with the support of the Ministry of Education within the project SGS 21122.

\section{References}

[1] ROUČKA, J. (1998). Metalurgie neželezných kovů. Akademické nakladatelství CERN, s.r.o. Brno (in Czech).

[2] GRÍGEROVÁ, T., KOŘENÝ. R., LUKÁČ, I. (1988). Zlievárenstvo neželezných kovov. (Foundry of non-ferrous metals). 1. vyd. Bratislava / Praha (in Slovak).

[3] MALCEV,M.V., BARSUKOVA, T.A. BORIN, F.A. (1963). Metalogrrafie neželezných kovov a zliatin (Metallography of non-ferrous metals and alloys), SNTL Praha/Bratislava (in Slovak).

[4] TURCHANIN, M.A., POROKHNYA, S.V. (1996). Heat of formation of liquid copper alloys with 3D transition metals. Powder Metallugand Metal Ceramics Vol. 35 No 7-8, July - August pp.64-75.

[5] COLLINI, L. (2012). Copper Alloys - Early Applications and Current Performance -Enhancing Processes. Intech, ISBN 978-953-51-0160-4.

[6] CENOZ, I. (2010). Metallography of aluminium bronze alloy as cast in permanent iron die. Association of metallurgical Enginnera of Serbia AMES. MJoM Vol. 16 (2). pp. 115 - 122.

[7] PÍŠEK, F. at. al. (1973). Nauka o materiálu I/3 Neželezné kovy. (Material Science I / 3 Non-ferrous metals). 2. rozšířené vydání Praha (in Czech).

[8] LIPIŇSKI, T. (2011). Microstructure and Mechanical properties of the AlSi13Mg1CuNi alloy with ecological modifier. Manufacturing technology. Vol. 11, No 11., 2011. pp. 40-44. ISSN 1213-2489.

[9] CAMPBELL, J. (2003). Casting. The new metalurgy of cast metals. Elsevier Butterworth-Heinemann Amsterodam. ISBN 0750647914.

[10] MICHNA, Š. VOJTĚCH, D. MAJRICH. P. (2008). Problematika kvality Al taveniny při lití automobilových disků. (Problems of quality of Al melt in the casting of automotive drives). Strojírenská technologie. Roč. XIII, prosinec č. 3, s. 17 - 23. ISSN 1211-4162 (in Czech).

[11] LICHÝ, P. BEŇO, J., CAGALA, M. (2013). Posibility of effecting the casting structureof magnesiul alloys. $M a-$ nufacturing Technology. Vol.13, No. 3, p. 341 - 345. ISSN 1213-2489.

[12] HONZÁTKO, R., MICHNA, Š. CAIS, J. (2013) The influence of porosity on mechanical properties of casts production from Al-Si alloys. Manufacturing Technology. Vol.13, No. 3, p. 319 - 324. ISSN 1213-2489.

[13] SVOBODOVA, J. (2014). SEM and EDS Analysis Used in Evaluation of Chemical Pre-treatment Based on Nanotechnology, Manufacturing Technology, Journal for Science, Research and Production, October, Vol. 14, No. 3 , ISSN 1213-2489. 